\title{
Генезис формування договірної бази регіонального співробітництва України та Республіка Польща
}

Сучасні міжнародні відносини характеризуються інтенсивними інтеграційними процесами, серед яких важливу роль відіграє транскордонне, регіональне та міжрегіональне співробітництво. Україна, завдяки вигідному геополітичному положенню має великі потенційні можливості щодо його розвитку.Але потрібно відмітити, що процес формування цих відносин має ряд особливостей. За часи існування незалежної України регіональне співробітництво формувалося під впливом ряду чинників,як зовнішніх так i внутрішніх, які мали значний вплив на такі процеси. Саме, ретроспективний огляд цих стосунків показує, що їхнє становлення відбувалося як складний i суперечливий процес, хоч в ньому домінували тенденції до порозуміння, взаємозближення двох сусідніх держав. Нормативно-правова база регіональних зв'язків між Україною і Республікою Польща з другої половини 90-х років значно наблизилась до кращих європейських зразків. Хоч в Україні потрібно було багато зробити для завершення формування національної законодавчої бази, яка б у повному обсязі визначила правові засади та регулювала регіональне співробітництво. Зокрема, фактом є те, що й після 1996 р., коли єврорегіони «Карпати» i «Буг» почали функціонувати, жоден закон України не визначав категоріального апарату щодо регіонального співробітництва $\mathrm{i}$ особливостей функціонування прикордонного регіону на зовнішньому ринку. 3 політичної точки зору, підтримка високого рівня транскордонних відносин України і Польщі, а втім України і ЄС, загалом сприяло становленню проринкової, прозахідної орієнтації українського суспільства, що позитивно вплинуло на увесь європейський інтеграційний процес.

Ключові слова: договір, договірно-правова база, двостороннє співробітництво, українськопольські стосунки, регіональне співробітництво, республіка Польша, угода, Україна.

Постановка наукової проблеми та її значення. Регіональне співробітництво є чинником стабільності, додатковим інструментом для досягнення порозуміння між народами, розвитку добросусідських відносин між державами, оскільки воно дає змогу вирішити негаразди економічного, соціального характеру, розв'язати проблеми територіальної і регіонів. В рамках регіональної політики України i Республіка Польща приділяється значна увага i фінансова підтримка транскордонному співробітництву.

Разом $з$ тим, сам процес наукового обговорення вказаної проблеми виступає органічною складовою сучасного типу українсько-польських зв'язків. Тобто, послідовне розширення упродовж 90-х років XX ст. договірно-правової бази політичних контактів, співробітництва в економічній, гуманітарній і інших сферах життя двох сусідніх народів, дає матеріали для теоретичних досліджень, i навпаки - постійне узагальнення досвіду такої співпраці, в тому числі й правореалізаційної практики, стає новим імпульсом для іiі активізації й удосконалення. При цьому, слід зазначити, що інформація про сучасний стан подібних відносин між Україною та Республікою Польща у багатьох вітчизняних і польських дослідженнях поєднується 3 переосмисленням досвіду двосторонніх відносин у попередні часи.

У нашому дослідженні ретроспективний огляд також слугує виявленню перших паростків майбутнього правового поля, перевірених часом, і сприйнятих або відкинутих в процесі багаторічної практики унормування двосторонніх відносин.

Аналіз досліджень цієї проблеми. Сьогодні активно досліджується тема регіонального співробітництва та його найвищої організаційної форми єврорегіонів. Автори виділяють різні типи, структуру та основні характеристики цих елементів. Питання регіональної політики, транскордонного співробітництва, його напрямів, позитивних ефектів та інших особливостей висвітлюються в працях таких вчених, як М. І. Долішній, П. В. Луцишин, М. А. Лендєл, П. Ю. Бєлєнький, Н. А. Мікула, Є. Е. Матвєєв, Ю. В. Макогон, А. І. Мокій, І. В. Студенніков, А. В. Вавринюк, Г. Возняк, М. І. Долішній, І. Ілько, Ю. М. Малиновська, М. Мальська, С. М. Писаренко В. П. Нагірна

(C) Гороть A., 2020 
Мета статті полягає в розкритті особливостей формування транскордонного співробітництва та функціонування єврорегіонів в Україні, та їх впливу на формування двостороннього співробітництва двох країн.

Виклад основного матеріалу й обгрунтування отриманих результатів дослідження. Як свідчить світова практика, міжрегіональні зв'язки є важливою і чи не найбільш поширеною сучасною формою міждержавних відносин. Особливо це стало помітним в умовах значного розширення правового поля міжнародного права на регулювання таких важливих сфер, як гуманітарні відносини, міжнародна безпека, міжнародна економіка, транскордонні зв'язки і ін.

Однією із найважливіших тенденцій розвитку європейських країн у другій половині XX століття стало посилення їх взаємозалежності, взаємопереплетення економік і формування спільного економічного простру. Перші активні спроби транскордонної співпраці в Європі припадають на кінець 60-х років. Це зумовлено тим, що останнім часом в умовах посилення глобалізації та міжнародної інтеграції, гостро постало питання регіоналізації в Європі. Адже регіональна співпраця між країнами сприяє більш ефективному використанню ресурсів та дозволяє вирішити ряд проблем, спільних для певною території. Таке співробітництво діє в межах транскордонних відносин між країнами. Транскордонні відносини - це сукупність будь - яких взаємозв'язків, що налагоджені на регіональному та місцевому рівнях з метою реалізації спільних інтересів територіальних громад прикордонних адміністративно - територіальних одиниць сусідніх країн.

У стосунках між Україною і Республікою Польща важливим щодо цього процесу фоктором у 90-ті роки став досить швидкий ріст міжнародної активності суб'єктів різних територіальних і галузевих утворень (областей, воєводств, районів, повітів, сільських рад, гмін, міст, відомств, підприємств, установ, закладів і т. д.), а отже - активізація договірного процесу і значне розширення договірно-правової бази, тобто збільшення кількості двосторонніх і багатосторонніх договорів, які за суб'єктним критерієм і за рівнем деталізації механізму в основному відповідають принципу взаємовигідності договірної норми міжрегіональних зв'язків.

90-ті роки започаткували якісно новий етап розвитку всіх форм транскордонного співробітництва, що реорганізувалося вже в умовах Української незалежної держави і демократичної Польщі. Уже в першому міждержавному акті - Декларації про принципи та основні напрямки розвитку українсько-польських відносин (13.10.1990р.) Сторони заявили про всебічне сприяння безпосередньому співробітництву українських та польських підприємств, виходячи 3 необхідності активізації i поглиблення торговельно-економічного, господарського та науково-технічного співробітництва (ст.6) [1]. Таким чином, один із важливих напрямів інтенсифікації українськопольських стосунків - транскордонне співробітництво, одержав власну правову підставу і можливість широкої законотворчості в цьому напрямку.

Особливо динамічним і плодотворним договірний процес був на початку 90-х років. Лише у 1991-1993 рр. прийнято близько 50 міждержавних документів, що стосувалися організаційних, правових і змістових питань налагодження регіональної, транскордонної (прикордонної), галузевої співпраці. Це закономірно. Адже на початку 90-х рp. зміни у зовнішній та внутрішній політиці східноєвропейських держав, а також економічна криза, яка охопила їх в перехідний період, призвели до розриву усталених зв'язків. Внаслідок цього українсько-польська співпраця на рівні міст і регіонів, яка тривалий час залишалася невикористаним резервом, тепер могла оперативно і суттєво заповнити вакуум, який утворився у ділових стосунках між обома країнами, Але для цього так само оперативно слід було сформувати нормативно-правову базу.

18 грудня 1991 р. з ініціативи польської сторони в Замості було проведено регіональну нараду представників прикордонних областей України та воєводств Польщі. Результатом зустрічі стало підписання Протоколу намірів про співпрацю прикордонних воєводств Республіки Польща і областей України [2]. Цим документом було покладено початок відновленню традиційних прикордонних зв'язків та міжрегіонального співробітництва України та Польщі.

На той час спільною проблемою двох країн була відсутність усталеного режиму і документів на перетин кордону, сучасних комунікацій у прикордонні, обладнаних шляхів для зручного й швидкого пересування людей і вантажів. Тому, першочерговим завданням стало вироблення нормативно-правової бази, яка б забезпечила нормальне функціонування співробітництва у сфері перевезень через українсько-польський державний кордон, підвищення пропускної спроможності пунктів пропуску та створення умов для належного контролю осіб, транспортних засобів і вантажів, а також забезпечення громадського порядку. Лише у 1992 р. 3 цього приводу було прийнято 4 важливих документи (договори, угоди, протоколи). Започаткувала цей процес Угода між Урядом України і Урядом Республіки Польща про пункти пропуску через державний кордон, (підписана у 
Варшаві 18 травня 1992 р. Угоду затверджено постановою КМ № 223 (223-93- n) від 25. 03 93p. і вона набрала чинності після обміну нотами [3]. Ці правила майже не зазнали істотних змін аж до введення Польщею у 2004 р. в однобічному порядку Шенгенського візового режиму для громадян України.

Значним кроком на цьому шляху стало прийняття окремої Угоди між Урядом України і Урядом Республіки Польща про залізничне сполучення через Державний кордон [4], (підписана у Варшаві 18. 06. 1992 р. набула чинності 1. 01. 94р.). Ї̈̈ сутність визначає посилання на ст.8 Договору між Україною і Республікою Польща про добросусідство, дружні відносини, а також на Угоду між Урядом Республіки Польща про пункти пропуску через Державний кордон. Текст Угоди, що складається 315 статей досить чітко і конкретно унормовав, 3 урахуванням внутрішнього (національного) і міжнародного права, всі необхідні дії для здійснення надійного залізничного сполучення через кордон.

Подальше удосконалення нормативно-правової бази співробітництва відбулося шляхом обговорення між делегаціями Республіки Польща і України, у Варшаві з 1 по 2 жовтня 1992 р. За наслідками обговорення питань повістки денної було підписано Протокол переговорів між делегаціями Польщі та України по розробці проекту Угоди про залізничне сполучення через Державний кордон [5].

3 прийняттям базового Договору (набув чинності 30. 12. 92 р.), стаття 10 якого проголошувала, що «Сторони сприятимуть встановленню і розвиткові безпосередніх зв'язків та співробітництва між регіонами, адміністративно-територіальними одиницями та містами Республіки Польща і України. Особлива увага приділятиметься прикордонному співробітництву. Сторони співпрацюватимуть у галузі перспективного планування розвитку прикордонних регіонів» [6], розпочався планомірний правотворчий процес фактично по всіх напрямках регіонального $\mathrm{i}$ транскордоного співробітництва.

Цьому сприяла і загальна зовнішньополітична ситуація. На початку 90-х рр. саме західні регіони України розглядалися польськими лідерами як потенційно найбільш привабливі для реалізації польської зовнішньої політики на Сході. Урядовці Республіки Польща всіляко підтримували і навіть активізували зусилля України, спрямовані на інтеграцію в європейські структури, надаючи виняткового значення транскордоному співробітництву. Маршал Сейму Ю. Зих, наголошуючи на доцільності розширення й активізації стосунків польських парламентарів 3 українськими колегами, підкреслював важливість організації зустрічі депутатів прикордонних областей України та воєводств Польщі $з$ метою поглиблення регіонального співробітництва. У відповідь Україна організувала у Львові першу зустріч ділових та представницьких кіл, на якій розглядалися питання українсько-польського міжрегіонального співробітництва [7, с. 71].

22 червня 1992 р. у Луцьку відбулося засідання українсько-польської змішаної комісії 3 участю представників органів влади, ділових людей Волинської, Львівської областей та Замостського, Холмського, Перемишльського, Кросненського воєводств, на якому було обговорено актуальні питання економічного співробітництва й регіонального розвитку: залучення іноземних інвестицій, створення спільних виробництв з випуску товарів народного споживання, медикаментів, техніки для фермерських господарств, переробки сільськогосподарської продукції, а також поглиблення співпраці у сфері культури, обміну інформацією, охорони навколишнього середовища, створення українсько-польського комерційного банку. За наслідками засідання було підписано Протокол намірів щодо розширення регіональної співпраці [8].

Розвиткові законотворчості активно сприяла Українсько-польська урядова координаційна комісія 3 питань міжрегіонального співробітництва. Саме тут готувався проект Угоди «Про співробітництво прикордонних воєводств - областей Польщі і України», підписаної 18 грудня 1992 p. [9], яка стала однією 3 важливих передумов розвитку міжрегіональних відносин між двома країнами. У ній вперше визначено правовий статус суб'єктів прикордонного співробітництва, чітко окреслено контактні зони по обидві сторони українсько-польського кордону.

Реальні позитивні зрушення відбулися у 1993 р. після приєднання України до Європейської рамкової конвенції про основні принципи транскордонного співробітництва між територіальними громадами або органами влади. Конвенція передбачала, зокрема, можливість підписання угод про транскордонну співпрацю між місцевими та регіональними органами влади, тобто підключення до активної правотворчості нижчого ешелону владних структур [7, с.73].

Дані нормативні напрацювання попередніх років стали грунтовною юридичною основою для підготовки і підписання 12 січня 1993 р. в м. Києві широкомасштабного Договору між Україною i Республікою Польща про правовий режим українсько-польського державного кордону, співробітництво та взаємну допомогу з прикордонних питань (Договір ратифіковано Постановою ВР 
№ 3379-12 від 14. 07. 93.) [10].

Даний Договір доповнювався окремими угодами та урядовими розпорядженнями 3 метою удосконалення або поглиблення окремих напрямів співпраці. До таких нормативних актів слід віднести Угоду між Урядом України і Урядом Республіки Польща про передачу і прийом осіб через спільний державний кордон; Угоду між Урядом України і Урядом Республіки Польща про залізничне сполучення через Державний кордон [11]; Про відкриття пункту пропуску через державний кордон України 3 Республікою Польща «Хирів» для двостороннього міждержавного пасажирського сполучення; Розпорядження КМ України від 7. 05.94 р. ; Про відкриття пункту пропуску «Рава Руська»; Розпорядження КМ України від 1. 06. 95 р. № 321 - p ; Угоду між Урядом України та Урядом Республіки Польща про будівництво автодорожного мосту через ріку Західний Буг на українсько-польському кордоні в районі пункту пропуску Ягодин - Дорогуськ і ін.

Протягом 1994-1996 р. на українсько-польському кордоні було відкрито, в рамках Договору про пункти пропуску через державний кордон, 6 міждержавних переходів, два 3 яких автомобільного пасажирського сполучення. У значній кількості укладалися угоди між областями України і воєводствами Польщі про співпрацю. 15-16 червня 1996 р. відбувся візит Л. Кучми у Польщу, під час якого президенти обох країн підписали Угоду про безвізовий туризм [9], яка значно спростила процедуру перетину кордону громадянами, скасувавши вимогу наявності ваучера. 18 серпня Угода увійшла в дію.

Незважаючи на певні успіхи, обидві сторони прагнули до виведення регіональної співпраці на більш вищий, сучасний рівень. 3 цією метою 24 травня 1993 р. у між урядами України і Республіки Польща була підписана Угода про міжрегіональне співробітництво [12]. В ній, зокрема, йдеться про орієнтири майбутнього співробітництва прикордонних областей України і Польщі в масштабах Карпатського і Євробузького регіонів - більш структорованих і самостійних в організаційноправовому відношенні формувань.

3 приводу цього у жовтні 1993 р. у Варшаві відбулася нарада представників адміністрації прикордонних областей і воєводств України, Білорусії і Польщі, на якій було вироблено принципово новий підхід до концепції регіонального співробітництва - утворення єврорегіону «Буг» яка отримала схвалення у штаб-квартирі Європейської співдружності в Страсбурзі, при умові, якщо він (єврорегіон) буде формуватися згідно вимог Протоколу до Європейської рамкової конвенції про транскордонне співробітництво між територіальними общинами або властями (995 106, «Рамкова конвенція») і Додаткового протоколу до «Рамкової конвенції» [13].

29 вересня 1995 р. у Волинській облдержадміністрації відбулося підписання двосторонньої Угоди про створення транскордонного об’ єднання «Єврорегіон Буг». В її преамбулі зазначається, що основними напрямами співробітництва новоствореного єврорегіону $\epsilon$ поєднання зусиль в економічній сфері, розбудові соціальної, інформаційної та виробничої інфраструктури, будівництві та модернізації інфраструктури кордону, розвитку транспортної мережі, науковій та культурній співпраці, охороні навколишнього природного середовища, обміні досвідом між відповідними органами виконавчої влади та органами місцевого самоврядування, взаємній допомозі в ліквідації наслідків надзвичайних ситуацій, боротьбі зі злочинністю і нелегальною міграцією тощо.

Висновки. Якщо оцінювати такі напрацювання 3 точки зору договірно-правового забезпечення регіональних зв'язків між Україною і Республікою Польща, то судячи із наведених вище численних фактів, вони були досить суттєвими. Без перебільшення, їх нормативно-правова база, особливо з другої половини 90-х років, значно наблизилась до кращих європейських зразків. Хоч і тут, зокрема, в Україні, потрібно було багато зробити для завершення формування національної законодавчої бази, яка б у повному обсязі визначила правові засади та регулювала регіональне співробітництво. Наприклад, фактом є те, що й після 1996 р., коли єврорегіони «Карпати» $\mathrm{i}$ «Буг» почали функціонувати, жоден закон України не визначав категоріального апарату щодо регіонального співробітництва i особливостей функціонування прикордонного регіону на зовнішньому ринку.

3 політичної точки зору, підтримка високого рівня транскордонних відносин України і Польщі, а втім України і СС, загалом сприяло становленню проринкової, прозахідної орієнтації українського суспільства, що позитивно вплинуло на увесь європейський інтеграційний процес.

\section{Джерела та література}

1.Декларація про принципи та основні напрями розвитку українсько-польських відносин // Україна на міжнародній арені. Збірник документів і матеріалів 1986-1990 р. p., - Київ: Україна, 1993. - С. 27- 
30.

2. Протокол намірів про співпрацю прикордонних воєводств РП і областей України (18.12.1991р.) // Архів МЗС України. - ОФ. - Спр. 6802. - Арк. 89.

3. Угода між Урядом України і Урядом Республіки Польща про пункти пропуску через Державний кордон. Варшава, 18.05.1992 р. (Угоду затверджено постановою КМ № 223 (223-93-п) від 25.03.93) [Електронний ресурс]. - Режим доступу: https://zakon.rada.gov.ua/laws/show/616_004\#Text.

4. Угода між Урядом України та Урядом Республіки Польща про будівництво автодорожного мосту через річку Західний Буг на українсько-польському державному кордоні в районі пункту пропуску Ягодин - Дорогуськ. м. Казіммеж Дольний, 22.01 .98 р. [Електронний ресурс]. - Режим доступу: https://zakon.rada.gov.ua/laws/show/616_100\#Text

5. Протокол переговорів між делегаціями Польщі та України по розробці проекту угоди про залізничне сполучення через Державний кордон. м. Варшава, 01.10.92 р. [Електронний ресурс]. Режим доступу: https://zakon.rada.gov.ua/laws/show/616_001\#Text.

6. Договір між Республікою Польща i Україною про добросусідства, дружні відносини i співробітництво (18.05.1992р.) [Електронний ресурс]. - Режим доступу: https://zakon.rada.gov.ua/ laws/show/616_172\#Text.

7. Васильєва О. І. Міжрегіональні зв'язки та транскордонне співробітництво - важлива складова сучасної державної регіональної політики України / О. І. Васильєва // Інвестиції: практика та досвід. 2010. - № 1. - С. 70-73.

8. Колесник В. Волинь - Замость, Люблін, Холм: прикордонні контакти в 2- й половині ХХ століття / В. Колесник // Україна - Польща: історія і сучасність. Збірник наукових статей і спогадів пам'яті Павла Михайловича Калениченка (1925-1983). Частина 2. - Київ, 2003. - С. 3-17.

9. Афанасьєв Т. Польсько-українські економічні стосунки у 1991-1997рp. / Т. Афанасьєв // Україна і Польща в XX столітті: проблеми і перспективи взаємовідносин. Збірник наукових праць. - Київ, 2002. - C. 126-131.

10. Договір між Україною і Республікою Польща про правовий режим українсько-польського державного кордону, співробітництво та взаємну допомогу 3 прикордонних питань. м. Київ, 12.01.93 p [Електронний ресурс]. - Режим доступу: https://zakon.rada.gov.ua/laws/show/616_208\#Text.

11. Угода між Урядом України та Урядом Республіки Польща про залізничне сполучення через Державний кордон. м. Варшава, 18.06.1993 р. (набула чинності 01.01.94) [Електронний ресурс]. Режим доступу: https://zakon.rada.gov.ua/laws/show/616_002\#Text.

12. Єврорегіон Буг: Волинська область / За ред. Б. П. Клімчука, П. В. Луцишина, В. Й. Лажніка. Луцьк: Ред.- вид. від. Волин. ун-ту, I997. - 448с.

13. Додатковий протокол до Європейської рамкової конвенції про транскордонне співробітництво між територіальними общинами або властями. м. Страсбург, 9.11.1995 р. [Електронний ресурс]. Режим доступу: https://zakon.rada.gov.ua/laws/show/994_099\#Text.

Гороть А. Генезис формирования договорной базы регионального сотрудничества Украины и Республики Польша. Современные международные отношения характеризуются интенсивными интеграционными процессами, среди которых важную роль играет трансграничное, региональное и межрегиональное сотрудничество. Украина, благодаря выгодному геополитическому положению, имеет большие потенциальные возможности для его развития. Но нужно отметить, что процесс формирования этих отношений имеет ряд особенностей. За время существования независимой Украины региональное сотрудничество формировалось под влиянием ряда факторов, как внешних, так и внутренних, которые оказали значительное влияние на такие процессы. Именно ретроспективный обзор этих отношений показывает, что их становление происходило как сложный и противоречивый процесс, хотя в нем доминировали тенденции к пониманию, взаимосближению двух соседних государств. Нормативно-правовая база региональных связей между Украиной и Республикой Польша со второй половины 90-х годов значительно приблизилась к лучшим европейским образцам. Хотя в Украине нужно было многое сделать для завершения формирования национальной законодательной базы, которая в полном объеме определила правовые основы и урегулировала региональное сотрудничество. В частности, фактом является то, что с 1996 г., когда еврорегионы «Карпаты» и «Буг» начали функционировать, ни один закон Украины не определял категориальный аппарат регионального сотрудничества и особенностей функционирования приграничного региона на внешнем рынке. С политической точки зрения поддержание высокого уровня трансграничных отношений Украины и Польши в общем способствовало становлению прорыночный, прозападной ориентации украинского общества, что положительно повлияло на весь 
европейский интеграционный процесс.

Ключевые слова: договор, договорно-правовая база, двустороннее сотрудничество, украинский-польские отношения, региональное сотрудничество, Республика Польша, Украина.

Horot A. Development of Regional Cooperation between Ukraine and the Republic of Poland: the Contractual Base Genesis. Modern international relations are characterized by intensive integration processes, among which cross-border, regional, and interregional cooperation plays an important role. Ukraine, due to its favorable geopolitical position, has great potential for its development. However, the process of inter-state relations formation has a number of specific features. Throughout the time of independent Ukraine, regional cooperation has been formed under the influence of a number of factors, both external and internal, which made a significant impact on these processes. A retrospective review of these relations genesis shows that their formation is a complex and contradictory process, although the tendency towards understanding and rapprochement between the two neighboring states has always dominated in it. The legislative framework for regional relations between Ukraine and the Republic of Poland has come much closer to the best European standards since the second half of the 1990s. Although a lot of things need to be done in Ukraine to complete the formation of a national legislative framework, which would fully define the legal framework and regulate regional cooperation. In particular, the fact is that even after 1996, when the «Carpathian» and «Bug» Euroregions began to function, no law of Ukraine defined the categorical apparatus according regional cooperation and the peculiarities of the functioning of the border region in the foreign market. From a political point of view, maintaining a high level of cross-border relations between Ukraine and Poland, and Ukraine in general, contributed to the formation of pro-market, pro-Western orientation of Ukrainian society, which had a positive impact on the entire European integration process.

Key words: agreement, legal framework, bilateral cooperation, Ukrainian-Polish relations, regional cooperation, Republic of Poland, Ukraine.

УДК 340.12

DOI https://doi.org/10.32782/2409-4544/2020-1/7

М. Копетюк

\section{Поняття та класифікація міжнародних стандартів прав людини та громадянина}

Стаття присвячена дослідженню правової основи міжнародних стандартів прав і свобод людини та громадянина. Проаналізовано наукові підходи до визначення поняття міжнародних стандартів прав людини і громадянина, а також розглянуті питання забезпечення прав і свобод людини і громадянина відповідно до міжнародних стандартів, закріплених в міжнародно-правових документах. Здійснено аналіз міжнародно-правових актів, які містять відповідні стандарти в сфері дотримання прав людини і громадянина, а також розглянуто їх класифікацію. Міжнародні стандарти прав людини є системою прав, які розкривають сучасну ідею прав людини, закріплену в основних міжнародно-правових документах і, відповідно, визнану в усьому світі. Стандарти основних прав $\mathrm{i}$ свобод людини і громадянина регулюються низкою міжнародно-правових актів, що визначають політичні, природні, культурні, соціальні права. Автор зробив висновок про те, що у основу Конституції України закладено принципово нові правові парадигми зовнішньої і внутрішньої державної політики України, що спрямовані на утвердження й забезпечення прав і свобод людини i громадянина. А це об'єктивно вимагає істотної переорієнтації та модифікації всієї національної правової системи. В Україні набуває поширення теорія визнання людської гідності, яка $\epsilon$ інтегративною властивістю природи людини та виступає як один з інституційних джерел ії основних прав. I з огляду на це у загальній теорії права сформульовано антропогенну інтерпретацію людської гідності, поняття якої визначається як самоцінність людини як унікальної біосоціальної істоти. На переконання автора, зазначені доктринальні позиції у ближній перспективі вимагатимуть відповідної

(C) Копетюк M., 2020 